\title{
Antioxidant activity of Matricaria chamomilla L. extract and clinical efficacy of cosmetic formulations containing this extract and its isolated compounds
}

\author{
Actividade antioxidante do extracto de Matricaria chamomilla L. e eficácia clínica de \\ formulações cosméticas contendo este extracto e seus compostos isolados
}

\author{
Ananda T. Nóbrega ${ }^{1}$, Tais A. L. Wagemaker ${ }^{1}$, Patricia M. B. G. Maia Campos ${ }^{1 *}$. \\ ${ }^{1}$ University of São Paulo, Faculty of Pharmaceutical Sciences of Ribeirão Preto, Brazil \\ *Avenida do Café, s/n, Ribeirão Preto, SP, Brazil, 14040-903, 551636024197 \\ Email:pmcampos@usp.br
}

\begin{abstract}
Topical application of antioxidants has proven to be effective in protecting the skin against oxidative damage. Matricaria chamomilla L. extract has been used in cosmetic formulations. The aim of this study was to evaluate the antioxidant potential of chamomile extract as well as the clinical efficacy on skin hydration and mechanical properties of skin. The antioxidant activity of chamomile extract was evaluated by chemiluminescence $($ IC50 $=$ $0.14 \mu \mathrm{g} / \mathrm{mL}$ ). Stable formulations were supplemented with $0,5 \mathrm{cg} / \mathrm{g} \alpha$-bisabolol or $\mathrm{cg} / \mathrm{gwith}$ 5,0 of Matricaria chamomile glycolic extract or with $0,01 \mathrm{cg} / \mathrm{g}$ of apigenin and applied on the volar forearm and face of 25 female subjects. Skin physiology was assessed before and after 2 hours (single application) and after a 2- and 4-week period of daily application. After a single application, all formulations increased the stratum corneum water content but only $\alpha$-bisabolol and chamomile extract formulations reduced TEWL. The formulation with chamomile extract has shown the most pronounced result in the reduction of TEWL (27\%). However, after 2- and 4-week application, only the extract formulation increased stratum corneum water content compared with the vehicle. Chamomile extract was effective in neutralizing free radicals and therefore presents an interesting potential in cosmetic formulations for this purpose.
\end{abstract}

Keywords: Chamomile, Clinical Efficacy, Antioxidant Activity, Apigenin, Alpha-Bisabolol,

\section{Resumo}

A aplicação tópica de antioxidantes provou ser eficaz em proteger a pele contra danos oxidativos. O extracto de Matricaria chamomilla L. tem sido amplamente utilizado em formulações cosméticas. Assim, o objectivo deste estudo foi avaliar o potencial antioxidante do extracto de camomila, bem como a eficácia clínica na hidratação e nas propriedades mecânicas da pele. A actividade antioxidante do extracto de camomila foi avaliada por quimioluminescência (IC50 = 0,14 ug / mL). As formulações foram suplementadas com a $\alpha$-bisabolol de fração mássica $0,5 \mathrm{cg} / \mathrm{g}$ ou com extracto glicólico de Matricaria chamomilla L. de fração mássica 5,0 cg/g ou com 0,01 $\mathrm{cg} / \mathrm{g}$ de apigenina e aplicados na parte interna do antebraço e na cara de 25 mulheres. A fisiologia da pele foi avaliada antes e após 2 horas (aplicação única) e 2 e 4 semanas de aplicação diária. Depois de uma única aplicação, todas as formulações aumentaram a água do estrato córneo, mas apenas as formulações com $\alpha$-bisabolol e extracto de camomila reduziram a PTEA. A formulação com o extracto de camomila mostrou o resultado mais marcante na redução PTEA (27\%). No entanto, após 2 - e 4- semanas de aplicação, apenas a formulação contendo o extracto aumentou o a água no estrato córneo. $\mathrm{O}$ extracto de camomila, foi eficaz na neutralização de radicais livres e, portanto, apresenta potencial em formulações cosméticas com este propósito.

Palavras-chave: Camomila, Eficácia Clínica, Actividade Antioxidant, Apigenina, Alfa-Bisabolol. 


\section{Introduction}

Skin is the outermost organ of the body, it is easily affected by the environment and it is constantly exposed to oxidative stress induced by reactive oxygen species (ROS). This oxidative damage in skin leads to melanocytic overproduction of melanosomes and to weakened elastin and collagen (1), induces expression of proinflammatory cytokines (IL-1, IL-6, and TNF-b) and inhibits apoptosis (2).

Topical administration of antioxidants has proven to be effective in protecting the skin against oxidative damage (3), and it provides the most straightforward way to strengthen the endogenous protection system (1). In addition, topical use of botanical extracts results in clinical improvement of skin conditions due to their antioxidant and anti-inflammatory properties $(4,5)$.

Besides antioxidant activities, botanical extracts have attracted great interest in the cosmetic and skin care area due to their rich composition and medicinal properties. Matricaria chamomilla L. extract is rich in flavonoids, terpenes, polysaccharides, among others, which may contribute for example anti-inflammatory and emollient effects to the formulations bioactive properties $(6$, $7,8)$. $\alpha$-bisabolol, an isolated compound from chamomile extract, has been reported as having antimicrobial (9), anti-inflammatory (10), anti-nociceptive (10), and antimalarial (11) activities. Apigenin, another isolated compound from chamomile extract, has been cited in the literature as protecting skin keratinocytes from ultraviolet-B induced Reactive Oxygen Species and DNA damage (12).

Normal skin barrier function is an essential aspect of skin homeostasis and regeneration. Among other properties, the stratum corneum represents an important barrier to the environment and protects the body from water loss and penetration of harmful substances and microorganisms (13). Therefore, in recent years there has been an increasing interest in evaluating cosmetic products for their ability to restore these protective properties.

Biophysical and skin imaging techniques have occupied a prominent position to evaluate the effectiveness of cosmetic and skin care products by objective, scientific and non-invasive methods. Using skin biophysical equipment it is possible to measure the hydration, elasticity and roughness of skin and, consequently, evaluate the efficacy of the cosmetic formulations on improvement of skin conditions, without any damage to the volunteers. Additionally, the feasibility of using biophysical and skin imaging techniques has been shown for a number of studies in the literature $(14,15$, $16,17)$

\section{Introdução}

A pele é o órgão mais externo do corpo, ele é facilmente afetado pelo ambiente e é constantemente exposto a estresse oxidativo induzido por espécies reativas de oxigênio (ROS). Este dano oxidativo na pele conduz à superprodução melanocítica de melanossomas e ao enfraquecimento da elastina e do colagénio enfraquecida (1), induz a expressão de citoquinas pró-inflamatórias (IL-1, IL-6 e TNF-b), e inibe a apoptose (2). A aplicação tópica de antioxidantes, tem provado ser eficaz em proteger a pele contra danos oxidativos (3), e fornece a maneira mais simples para reforçar o sistema de protecção endógena (1). Além disso, o uso tópico de extractos botânicos resulta em melhoria clínica das condições da pele, devido às suas propriedades antioxidantes e anti-inflamatórias $(4,5)$.

Além das aticvidades antioxidantes, os extractos botânicos têm atraído grande interesse na área de cosméticos e cuidados da pele devido à sua rica composição e às suas propriedades medicinais. O extracto de Matricaria chamomilla L. é rico em flavonoides, terpenos, polissacarídeos, entre outros, que podem fornecer para as formulações propriedades bioactivas, tais como efeitos anti-inflamatório e emoliente $(6,7,8)$. O composto isolado a partir de extracto de camomila $\alpha$-bisabolol foi avaliado como tendo actividades antimicrobianas (9), anti-inflamatórias (10), anti-nociceptivas (10) e antimaláricas(11). A apigenina, outro composto isolado a partir de extracto de camomila, tem sido citado na literatura como protetor dos queratinócitos da pele quando submetidos a ação de Espécies Reativas de Oxigênio (EROs) induzidas pela radição ultravioleta-B e danos ao DNA (12).

A função normal da barreira da pele é um aspecto essencial da homeostase e da regeneração da pele. Entre outras propriedades, o estrato córneo representa uma importante barreira para o meio ambiente e protege o corpo contra a perda de água e penetração de substâncias nocivas e microorganismos (13). Desta forma, nos últimos anos, tem havido um interesse crescente em produtos cosméticos para avaliar a sua capacidade para restaurar estas propriedades protectoras. Técnicas de biofísica e imagem da pele têm ocupado uma posição de destaque para avaliar a eficácia de produtos cosméticos e de cuidados da pele por métodos objetivos, científicos e não-invasivos. Usando equipamentos de biofísica da pele é possível medir a hidratação, a elasticidade e a rugosidade da pele e, consequentemente, avaliar a eficácia das formulações cosméticas sobre a melhoria das condições da pele, sem qualquer dano para os voluntários. Além disso, a possibilidade de utilizar técnicas de biofísicas e imagem da pele tem sido demonstradas por vários estudos na literatura $(14,15,16,17)$. 
Although it is possible to find in the literature several studies concerning chamomile extract, to the best of our knowledge, there is a lack of studies about topical formulations containing chamomile extract and its isolated compounds. Thus, the aim of this study was to evaluate the antioxidant potential of chamomile extract as well as the efficacy of a cosmetic formulation containing chamomile extract or its isolated compounds, on hydration and mechanical properties of skin.

\section{Material and methods}

\section{Antioxidant activity assay}

In vitro antioxidant activity was measured by chemiluminescence assay (CL) using a protocol adapted from Nile et al (18).

\section{Sample preparation}

Sample preparation started with both the stock solutions of chamomile extract $(0.5 \mathrm{~g} / \mathrm{mL})$ and apigenin $(1.05 \mathrm{mg} / \mathrm{mL})$ in $50 \mathrm{cg} / \mathrm{g}$ solution of dimethylsulfoxide (DMSO). The samples, chamomile extract solution and apigenin solution, were further diluted in $50 \%$ solution of DMSO, to obtain the final concentrations of $0.5 \mu \mathrm{g} /$ $\mathrm{mL}, 0.25 \mu \mathrm{g} / \mathrm{mL}, 0.125 \mu \mathrm{g} / \mathrm{mL}, 0.06 \mu \mathrm{g} / \mathrm{mL}$ and 0.03 $\mu \mathrm{g} / \mathrm{mL}$ for the chamomile extract samples and $1.0510^{-5}$ $\mu \mathrm{g} / \mathrm{mL}, 0.52510^{-5} \mu \mathrm{g} / \mathrm{mL}, 0.26310^{-5} \mu \mathrm{g} / \mathrm{mL}, 0.13110^{-5}$ $\mu \mathrm{g} / \mathrm{mL}$ and $0.06610^{-5} \mu \mathrm{g} / \mathrm{mL}$ for the apigenin samples. Ten $\mu \mathrm{L}$ of each sample solution in different concentrations, containing chamomile extract and apigenin or a positive control solution (without any active substance, which yields $100 \%$ of free- radical production) was mixed with $0.1 \mathrm{M}$ phosphate buffer $(\mathrm{pH}=7,4)$, and 2 $\mathrm{mg} / \mathrm{mL}$ luminol solution was added to yield a final concentration of $1,1310^{-4} \mathrm{M} . \mathrm{H}_{2} \mathrm{O}_{2}$ which was then added to a final $510^{-5} \mathrm{M}$ concentration.

The reaction was started by adding HRP at a final concentration of $0,2 \mathrm{IU} / \mathrm{mL}$ and ompleting the solution final volume to $1,0 \mathrm{~mL}$ (15). Chemiluminescence experiments were done in an Autolumat LB953 apparatus (EG \& G Berthold, U.S.A.). The chemiluminescence integrated area, i.e. the area under the time-course curve of chemiluminescence $(A U C)$, was reported in terms of mean and standard deviation of three determinations and represents the total of ROS produced in the medium in $15 \mathrm{~min}$ at $30^{\circ} \mathrm{C}$. The inhibition ratio (\%) of each sample was calculated as:

Inhibition $(\%)=100 \times A U C_{1} / A U C_{0}$;

where $A U C_{0}$ and $A U C_{1}$ represent the area under the
Embora seja possível encontrar na literatura vários estudos com extracto de camomila, para o melhor de nosso conhecimento, há falta de estudos sobre formulações tópicas contendo extracto de camomila e seus compostos isolados. Assim, o objectivo deste estudo foi avaliar o potencial antioxidante do extracto de camomila, bem como, a eficácia de uma formulação cosmética contendo extracto de camomila ou os seus compostos isolados na hidratação e as propriedades mecânicas da pele.

\section{Material e métodos}

\section{Ensaio de actividade antioxidante}

A actividade antioxidante in vitro foi medida por ensaio de quimiluminescência, utilizando um protocolo adaptado a partir de Nilo et al (18).

\section{Preparação das amostras}

A preparação das amostras começou as soluções de extracto de camomila $(0,5 \mathrm{~g} / \mathrm{mL})$ e a apigenina $(1,05 \mathrm{mg} /$ $\mathrm{mL}$ ) em solução a $50 \%$ de dimetilsulfóxido (DMSO). As amostras, a solução de extracto de camomila e solução de apigenina, foram diluídas em solução de $50 \mathrm{cg} / \mathrm{g}$ de DMSO, para se obter as concentrações finais de $0,5 \mu \mathrm{g} /$ $\mathrm{mL}, 0,25 \mu \mathrm{g} / \mathrm{mL}, 0,125 \mu \mathrm{g} / \mathrm{mL}, 0,06 \mu \mathrm{g} / \mathrm{mL}$ e $0,03 \mu \mathrm{g} /$ $\mathrm{mL}$ para as amostras de extracto de camomila, e 1,05 10-5 $\mu \mathrm{g} / \mathrm{mL}, 0,52510^{-5} \mu \mathrm{g} / \mathrm{mL}, 0,26310^{-5} \mu \mathrm{g} / \mathrm{mL}, 0,13110^{-5}$ $\mu \mathrm{g} / \mathrm{mL}$ e $0.06610^{-5} \mu \mathrm{g} / \mathrm{mL}$ para as amostras de apigenina . Dez $\mu \mathrm{L}$ de cada solução de amostra, em diferentes concentrações, que contém extracto de camomila e apigenina ou uma solução de controlo positivo (sem qualquer substância activa, que produz 100 \% da produção de radicais livres) foram misturadas com tampão $0,1 \mathrm{M}$ $(\mathrm{pH}=7,4)$, e $2 \mathrm{mg} / \mathrm{mL}$ de solução de luminol foi adicionado para uma concentração final de $1,1310^{-4} \mathrm{M}$. $\mathrm{H}_{2} \mathrm{O}_{2}$ foi então adicionado a uma concentração final de $510^{-5} \mathrm{M}$. A reacção foi iniciada por adição de HRP a uma concentração final de $0,2 \mathrm{UI} / \mathrm{mL}$, e completando o volume da solução final de 1,0 mL (15). Os experimentos de quimiluminescência foram realizados em um aparelho LB953 Autolumat (EG \& G Berthold, EUA) . A área integrada de quimiluminescência, isto é, a área sob a curva de quimiluminescência $(A U C)$, foi relatada em termos de média e desvio padrão de três determinações e representa o total de ROS produzidas no meio em 15 min a $30{ }^{\circ} \mathrm{C}$. A razão de inibição (\%) de cada amostra foi calculada como:

Inibição $(\%)=100 \times A U C_{1} / A U C_{0}$;

Onde $A U C 0$ e $A U C 1$ representam a área sob a curva 
curve observed for the control and in the presence of the sample solution, respectively.

\section{Formulations}

A stable emulsion based on methylphenyl polysiloxane (Net FS ${ }^{\circledR}$, Galena, Brazil), ethyloxanoato of ethhylexyl (Dagoxat ${ }^{\circledR}$ EH, Symrise, Galena, Brazil), glycerine (PA, Mapric, Brazil), propylenoglycol (PA, Synth, Brazil), cyclomethicone (DC245 ${ }^{\circledR}$, Dow Corning, Brazil), cyclomethicone and dimethicone crosspolymer (DC9040 ${ }^{\circledR}$, Dow Corning, Brazil), ammonium acryloyldimethyltaurate/VP copolymer (Hostacerin SAF ${ }^{\circledR}$, Clariant, PharmaSpecial, Brazil), phenoxyethanol and parabens (Phenonip ${ }^{\circledR}$, Clariant, PharmaSpecial, Brazil) and distilled water $-\mathrm{F} 1$ was prepared and supplemented with $\alpha$-bisabolol (Centroleo/Galena, Brazil) - F2, of $0,5 \mathrm{cg} / \mathrm{g}$ mass fraction, or with Matricaria chamomile glycolic extract (chamomile) (Alban Muller International, France) $-\mathrm{F} 3$, of $5,0 \mathrm{cg} / \mathrm{g}$ mass fraction or with apigenin $\left(95 \% \mathrm{n}^{\circ} 117 \mathrm{~K} 1420\right.$, Sigma Aldrich, Brazil) $\mathrm{F} 4$, of $0,01 \mathrm{cg} / \mathrm{g}$ mass fraction. The formulations were considered stable after having passed preliminary stability tests: organoleptic characteristics, $\mathrm{pH}$, centrifugation and rheological behavior.

\section{Study protocol}

Approval for the study was obtained from the Faculty of Pharmaceutical Sciences of Ribeirão Preto - USP Ethics Committee (CEP/FCFRP 135/2008). Twentyfive healthy female subjects between 20 years and 30 years old, having skin Fitzpatrick types II, III and IV, participated in this study, after have given their informed consent.

The exclusion criteria were: presence of any dermatitis and/or other skin or allergic diseases, smokers and previous treatment of skin forearms and face with cosmetic formulations such as moisturizers, sunscreens or anti-aging cosmetics.

During the test period, the subjects were allowed to wash their arms and face normally, but were instructed not to use any other skin care products on the areas under study.

Prior to all measurements, subjects remained in the room for at least $20 \mathrm{~min}$ in order to allow skin adaptation to room temperature $\left((22 \pm 2){ }^{\circ} \mathrm{C}\right)$ and humidity (between $45 \% 60 \%$ ) (17).

The forearm skin area of each volunteer was demarked in two regions in one forearm, and three regions in the other, both of them $36 \mathrm{~cm}^{2}$ each. The formulations studied and the measurement regions were randomized.

\section{Effects after a single application}

After the baseline measurements, $0,2 \mathrm{~g}$ of each formulation $(\mathrm{F} 1$ - vehicle, $\mathrm{F} 2$ - vehicle with $\alpha$-bisabolol of observada para o controlo e na presença da solução de amostra, respectivamente.

\section{Formulações}

Uma emulsão estável com base em methylphenyl polysiloxane (Net FS ${ }^{\circledR}$, Galena, Brazil), ethyloxanoato of ethhylexyl (Dagoxat ${ }^{\mathbb{B}} \mathrm{EH}$, Symrise, Galena, Brazil), glycerine (PA, Mapric, Brazil), propylenoglycol (PA, Synth, Brazil), cyclomethicone (DC245 ${ }^{\circledR}$, Dow Corning, Brazil), cyclomethicone and dimethicone crosspolymer (DC9040 ${ }^{\circledR}$, Dow Corning, Brazil), ammonium acryloyldimethyltaurate/VP copolymer (Hostacerin $\mathrm{SAF}^{\circledR}$, Clariant, PharmaSpecial, Brazil), phenoxyethanol and parabens (Phenonip ${ }^{\circledR}$, Clariant, PharmaSpecial, Brazil) e água destilada - F1 - foi preparada e adicionada com $\alpha$ -bisabolol (Centroleo / Galena, Brasil) - F2, de fração mássica $0,5 \mathrm{cg} / \mathrm{g}$ ou com extracto glicólico de Matricaria chamomilla L. (camomila) (Alban Muller internacional, França) - F3, de fração mássica $5,0 \mathrm{cg} / \mathrm{g}$ ou com apigenina $\left(95 \%\right.$ n ${ }^{\circ} 117$ K1420, Sigma Aldrich, Brasil) - F4, de fração mássica $0,01 \mathrm{cg} / \mathrm{g}$. As formulações foram considerados estáveis após passaram por testes de estabilidade preliminares: características organolépticas , $\mathrm{pH}$, centrifugação e comportamento reológico.

\section{Protocolo de estudo}

Aprovação para o estudo foi obtida a partir da Faculdade de Ciências Farmacêuticas de Ribeirão Preto - USP Comitê de Ética (CEP / FCFRP 135/2008). Vinte e cinco indivíduos saudáveis do sexo feminino entre 20 anos e 30 anos de idade, tipo de pele Fitzpatrick tipos II, III e IV, participaram deste estudo, depois de ter dado o seu consentimento informado. Os critérios de exclusão foram: presença de qualquer dermatite e / ou outra doenças alérgicas de pele, fumantes e tratamento anterior da pele dos antebraços e da cara com formulações cosméticas, como hidratantes, protetores solares ou cosméticos anti-envelhecimento. Durante o período de teste, os indivíduos foram autorizados a lavar os braços e a cara normalmente, mas foram instruídos a não usar quaisquer outros produtos de cuidados da pele nas áreas em estudo. Antes de todas as medições, os indivíduos permaneceram na sala durante pelo menos 20 minutos, a fim de permitir a adaptação da pele até à temperatura ambiente $\left((22 \pm 2){ }^{\circ} \mathrm{C}\right)$ e humidade (entre 45 e $\left.60 \%\right)(17)$. A área de pele do antebraço de cada voluntária foi demarcado em duas regiões em um antebraço e, três regiões do outro, ambos de $36 \mathrm{~cm}^{2}$ cada . As formulações estudadas e as regiões de medição foram randomizados.

\section{Efeitos após uma única aplicação}

Após as medições basais, $0,2 \mathrm{~g}$ de cada formulação (F1 - veículo, F2-veículo com $\alpha$-bisabolol, de fração mássi- 
$0,5 \mathrm{cg} / \mathrm{g}$ mass fraction, F3 - vehicle with chamomile extract of 5,0 cg/g mass fraction, F4 - vehicle with apigenin of $0,01 \mathrm{cg} / \mathrm{g}$ mass fraction) was applied on the volar forearm and on the face in the different sites. Two hours after the application new measurements were carried out (4).

\section{Effects after 2- and 4-weeks period of applications}

After the baseline measurements, $0.2 \mathrm{~g}$ of the formulations (F1 - vehicle, F3 - vehicle with $5.0 \%$ of chamomile extract, $\mathrm{F} 4$ - vehicle with $0.01 \%$ of apigenin) was applied on the volar forearm different sites and on the face, twice daily, in the morning and at night. Two and four weeks after application, new measurements were carried out, 10-15 $\mathrm{h}$ after the last treatment, i.e. the formulations were applied at night and the measurements were taken the following day.

\section{Instrumentation}

Stratum corneum water content was measured using a skin capacitance meter (Corneometer ${ }^{\circledR}$ TM CM 825, Courage \& Khazaka Electronic GmbH, Cologne, Germany). The device determines the water content of the superficial epidermal layers down to a depth of about $0.1 \mathrm{~mm}$ and expresses the values in arbitrary units. The average values of 10 measurements per site were used in subsequent calculations (16).

Transepidermal water loss (TEWL) was measured with an evaporimeter (Tewameter ${ }^{\circledR}$ TM 210, Courage \& Khazaka Electronic $\mathrm{GmbH}$, Cologne, Germany), and registered in $\mathrm{g} \mathrm{m}^{-2} \mathrm{~h}^{-1}$ during $2 \mathrm{~min}$, after probe equilibration on the skin for $90 \mathrm{~s}$ (19).

Skin microrelief parameters were evaluated using Visioscan $^{\circledR}$ VC98 and software SELS 2000 from Courage \& Khazaka Electronic Gmbh (Cologne, Germany). The measuring area was $6 \mathrm{~mm} \times 8 \mathrm{~mm}$ and an image of the skin was taken by a built-in CCD camera. The SELS (Surface Evaluation of the Living Skin) method is based on a graphic depiction of the living skin under special illumination, and the electronic processing and evaluation of this image was carried out according to four clinical parameters: a) Skin smoothness (Sesm) is calculated from the average width and depth of the wrinkles, $b$ ) Skin roughness (Ser) - is the roughness parameter and calculates the gray levels above the threshold in comparison with the entire image (reflects the 'asperity' of the skin.), and c) Scaliness (Sesc) - shows the level of dryness of the stratum corneum and is the number of pixels where the gray level is higher than the threshold of Sesc, d) Wrinkles (Sew) - is calculated from the proportion of horizontal and vertical wrinkles (17).

Mechanical properties of the skin were determined with ca $0,5 \mathrm{cg} / \mathrm{g}, \mathrm{F} 3$ - veículo com extracto de camomila, de fração mássica $5,0 \mathrm{cg} / \mathrm{g}, \mathrm{F} 4$-veículo com apigenina, de fração mássica $0,01 \mathrm{cg} / \mathrm{g}$ ) foram aplicadas em diferentes locais sobre a parte interna do antebraço e da cara. Duas horas após a aplicação novas medições foram realizadas (4).

\section{Efeitos após 2 - e 4-semanas de aplicações}

Após as medições basais, 0,2 $\mathrm{g}$ das formulações (F1 veículo, F3 - veículo com 5,0\% de extracto de camomila, F4-veículo com $0,01 \%$ de apigenina) foram aplicadas em diferentes locais na parte interna do antebraço e na cara, duas vezes por dia, de manhã e à noite. Duas a quatro semanas após a aplicação, novas medições foram realizadas, 10-15 horas após o último tratamento, isto é, as formulações foram aplicadas durante a noite e as medições foram realizadas no dia seguinte.

\section{Instrumentação}

O teor de água estrato córneo foi medido usando um medidor de capacitância da pele (Corneometer ${ }^{\circledR}$ TM CM 825, Courage \& Khazaka Electronic GmbH, Cologne, Alemanha). O dispositivo determina o conteúdode água das camadas epidérmicas superficiais até uma profundidade de cerca de $0,1 \mathrm{~mm}$ e expressa os valores em unidades arbitrárias. Os valores médios de 10 medições por local foram utilizados nos cálculos posteriores (16). A perda transepidérmica de água (PTEA) foi medida com um evaporímetro (Tewameter ${ }^{\circledR}$ TM 210, Courage \& Khazaka Electronic $\mathrm{GmbH}$, Cologne, Alemanha), e registrado em $\mathrm{g} \mathrm{m}^{-2} \mathrm{~h}^{-1}$ durante 2 min após o equilíbrio sonda na pele por $90 \mathrm{~s}$ (19). Os parâmetros do microrrelevo da pele foram avaliadas por meio Visioscan ${ }^{\circledR}$ VC98 e software SELs 2000 de Courage \& Khazaka Electronic GmbH (Cologne, Alemanha). A área de medida foi de $6 \mathrm{~mm} \times 8 \mathrm{~mm}$ e a imagem da pele foi feita por uma câmara embutida CCD. A ABSP (Avaliação Bruta da Superfície da Pele) método que se baseia na representação gráfica da pele viva, sob iluminação especial, e o processamento electrónico desta imagem foi realizada de acordo com quatro parâmetros clínicos: a) a suavidade da pele (SESM) - é calculada a partir da largura e profundidade média das rugas, $b$ ) a rugosidade da pele (Ser) - é o parâmetro de rugosidade e calcula os níveis de cinza acima do limite em comparação com a imagem inteira (reflecte a "aspereza " da pele), c) descamação ( Sesc ) - mostra o nível de secura do estrato córneo . É o número de pixels em que o nível de cinza é maior do que o limiar de SESC, d) Rugas (Sew) - é calculada a partir da proporção de rugas horizontais e verticais (17). As propriedades mecânicas da pele foram determinadas com um medidor de não-invasivo de sucção da elasticidade da pele (Cutometer ${ }^{\circledR}$ SEM 474, Courage \& Kha- 
a non-invasive suction skin elasticity meter (Cutometer ${ }^{\circledR}$ SEM 474, Courage \& Khazaka Electronic GmbH, Cologne, Germany). For this, a $2 \mathrm{~mm}$ diameter measuring probe was used and a constant suction of $450 \mathrm{mbar}$ for $1 \mathrm{~s}$ was applied followed by a relaxation time of 1 $\mathrm{s}$, with 5 repetitions. Measurements were made on the right temporal region and right volar forearm.

\section{Statistical analysis}

The differences for each volunteer in week 4 , week 2 and day 0 , as well as the differences for each volunteer between 0 and $2 \mathrm{~h}$ were calculated and the average was obtained. The results of application of treatments were analyzed using 1-way ANOVA. Whenever ANOVA showed significant differences, the Tukey HSD test was introduced. All analyses were performed using Minitab 16. Differences were accepted as statistically significant at $P<0,05$.

\section{Results}

\section{Antioxidant activity assay}

The antioxidant activity was assessed by the luminolchemiluminscence method. According to Nile (18), the promising characteristic of this method is their productivity; commonly, one run takes a few minutes only; in addition, the assay can be easily automated and run in microwell plates. Chamomile extract showed IC50 = $0.14 \mu \mathrm{g} / \mathrm{mL}$ as depicted in Figure 1 . zaka Electronic GmbH, Cologne, Alemanha). Para isso, utilizou-se uma sonda de medição de diâmetro de $2 \mathrm{~mm}$ e foi aplicada uma sucção constante de 450 mbar durante $1 \mathrm{~s}$, seguido por um tempo de relaxação de $1 \mathrm{~s}, 5$ repetições. As medições foram feitas na região temporal direita e na região interna do antebraço direito.

\section{Análise estatística}

As diferenças para cada voluntário na semana 4, na semana 2 e no dia 0 , bem como, as diferenças para cada voluntário entre 0 e 2 horas foram calculados com a média foi obtida. Os resultados da aplicação dos tratamentos foram analisados utilizando uma ANOVA. Sempre que ANOVA mostrou diferenças significativas, foi introduzido o teste de Tukey. Todas as análises foram realizadas utilizando Minitab 16. As diferenças foram aceitas como estatisticamente significativos $\operatorname{com} P<0,05$.

\section{Resultados}

\section{Ensaio de actividade antioxidante}

A atividade antioxidante foi avaliada pelo método de quimioluminescência dependente do luminol. De acordo com Nilo (18), a característica promissora deste método é a sua produtividade; comumente, uma execução dura poucos minutos e, além disso, o ensaio pode ser facilmente automatizado, e executado em placas de microcavidades. $\mathrm{O}$ extracto de camomila mostrou IC50 = $0,14 \mu \mathrm{g} / \mathrm{mL}$, conforme ilustrado na Figura 1 .

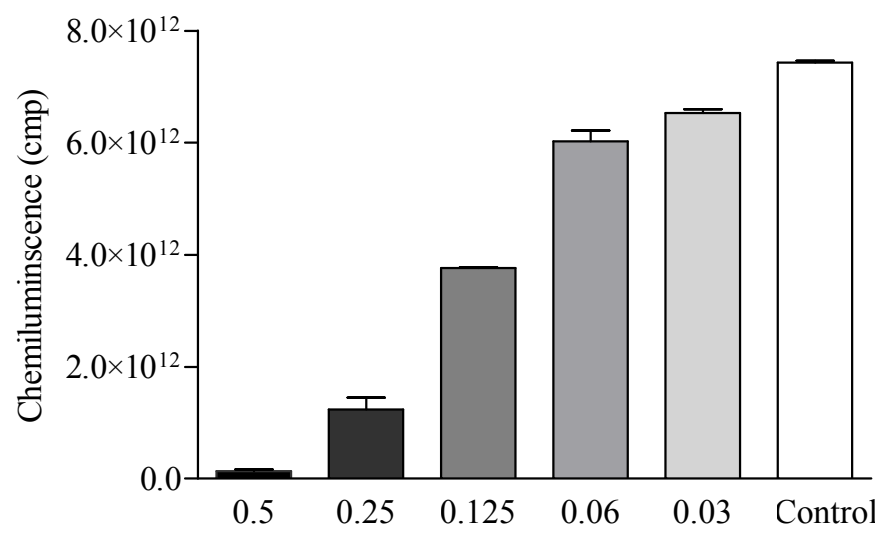

Chamomile extract concentration $(\mu \mathrm{g} / \mathrm{mL})$

Figure 1 - Concentration-response profile of chamomile extract in terms of antioxidant activity, as evaluated by the chemiluminscence assay.

Figura 1 - Perfil de dose-resposta do extracto de camomila em termos de atividade antioxidante, avaliada pelo ensaio de quimioluminescência dependente do luminol. 


\section{Effects after a single application}

In this study, two methods were used to evaluate the skin hydration after a single application of the formulations containing or not $\alpha$-bisabolol (F2), chamomile extract (F3) and apigenin (F4).

The first method was based on measurements of stratum corneum water content using a skin capacitance meter which enabled us to observe that the formulations containing $\alpha$-bisabolol (F2) and chamomile extract (F3) showed the best values of this parameter on the volunteers' forearm (Fig.1). There was an increment of almost $30 \%$ in stratum corneum water content after a single application 2 hours previously of the formulation with chamomile extract (F3), compared to the vehicle (F1), the formulation containing apigenin (F4) and the control (without application).

The efficacy of the increment of the stratum corneum water content was also evaluated on the face of the volunteers. For this, the formulations with chamomile extract (F3) or apigenin (F4) were applied with the aim of comparing the effects of the isolated compound and the synergic effects of this botanical extract. Once more, chamomile extract showed the best values (Figure 2).

\section{Efeitos após uma única aplicação}

Neste estudo, foram utilizados dois métodos para avaliar a hidratação da pele, após uma única aplicação das formulações contendo ou não $\alpha$ - bisabolol (F2), extracto de camomila (F3) e apigenina (F4). $\mathrm{O}$ primeiro método aplicado foi baseado em medições do teor de água do estrato córneo, utilizando um medidor de capacidade de pele que permitiu observar que as formulações contendo $\alpha$-bisabolol (F2) e extracto de camomila (F3) apresentaram os melhores valores para este parâmetro no antebraço das voluntárias (Fig.1 ). Comparando com o veículo (F1), a formulação que contém apigenina (F4) e o controlo (sem aplicação) após duas horas de uma única aplicação da formulação com extracto de camomila (F3) resultou num aumento de quase $30 \%$ no conteúdo de água do estrato córneo água. Aeficácia do incremento do teor de água do estrato córneo foi também avaliada na face das voluntárias. Para isso, foram aplicadas às formulações com extracto de camomila (F3) ou apigenina (F4), com o objectivo de comparar os efeitos do composto isolado e, os efeitos sinérgicos deste extracto botânico. Mais uma vez, o extracto de camomila apresentarou os melhores valores (Figura 2).

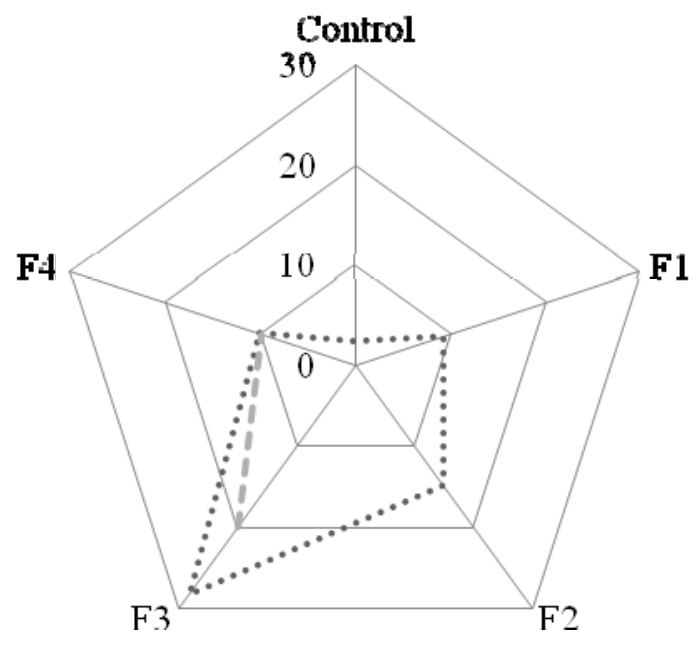

Figure 2 - Increment (\%) of stratum corneum water content after 2 hours single application of the formulations under study on the forearm (...) and on the face (---). Control - without treatment, F1 - vehicle, F2 - vehicle with $\alpha$-bisabolol of $0,5 \mathrm{cg} / \mathrm{g}$ mass fraction, F3 vehicle with Matricaria chamomile glycolic extract of 5,0 cg/g mass fraction, F4 - vehicle - with apigenin of 0,01 cg/g mass fraction.

Figura 2 - Incremento (\%) do teor de água do estrato córneo, após 2 horas de única aplicação das formulações em estudo sobre o antebraço (...) e na cara (---). Controle - sem tratamento, F1 - veículo, F2 - veículo com $\alpha$-bisabolol, de fração mássica 0,5 cg/g, F3 veículo com extracto glicólico de Matricaria chamomilla L. de fração mássica 5,0 cg/g, F4 - veículo - com apigenina, de fração mássica $0,01 \mathrm{cg} / \mathrm{g}$. 
The other method used in this study to measure the skin hydration was the transepidermal water loss (TEWL). It is considered the gold standard for characterization of the skin barrier function (13). Under the conditions of this study, the formulations contributed to decrease the transepidermal water loss on the forearm of the volunteers, especially the formulation with chamomile extract (Figure 3).

The same could be observed when the formulations containing chamomile extract (F3) and apigenin (F4) were applied on the face of the volunteers, i.e. there was a decrease in the transepidermal water loss, but it was not statistically significant (Figure 2). The formulations applied on skin of the face also showed no significant differences comparing 0 and $2 \mathrm{~h}$ after a single application.
O outro método utilizado neste estudo para medir a hidratação da pele foi a perda transepidérmica de água (PTEA). Este é considerado o padrão ouro para a caracterização da função de barreira da pele (13). Sob as condições deste estudo, as formulações contribuíram para diminuir a perda transepidérmica de água no antebraço das voluntárias, em especial a formulação com extracto de camomila (Figura 3). O mesmo pôde ser observado quando as formulações contendo extracto de camomila (F3) e apigenina (F4) foram aplicadas na cara das voluntárias, isto é, houve um decréscimo na perda transepidérmica de água, mas não foi estatisticamente significativa (Figura 2). As formulações aplicadas na pele da cara também não apresentaram diferenças significativas comparando 0 e 2 horas após uma única aplicação.

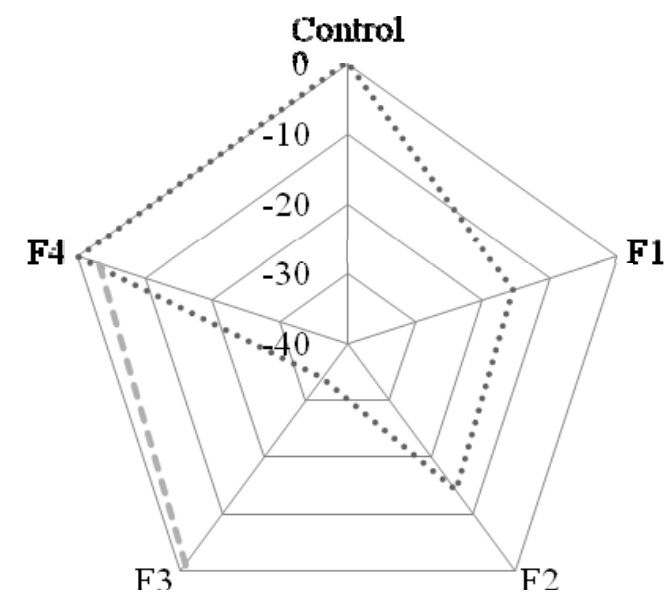

Figure 3 - Decrease (\%) of the transepidermal water loss 2 hours single application of the formulations under study on the forearm (...) and on the face (---). Control - without treatment, F1 - vehicle, F2 - vehicle with $0.5 \%$ of $\alpha$-bisabolol, F3 vehicle with $5.0 \%$ of Matricaria chamomile glycolic extract, F4 - vehicle - with $0.01 \%$ of apigenin.

Figura 3 - Redução (\%) da perda de água transepidérmica após 2 horas de única aplicação das formulações em estudo sobre o antebraço (...) e na cara (---). Controle - sem tratamento, F1 - veículo, F2 - veículo com 0,5\% de $\alpha$-bisabolol, F3 veículo com 5,0\% de extracto glicólico de Matricaria chamomilla L., F4 - veículo - com 0,01\% de apigenina.

In this study, the effects on skin microrelief after a single application of the formulations were assessed by Visioscan ${ }^{\circledR}$ but the results did not show significant differences among the treatments studied (data not shown). The mechanical properties of skin were evaluated using a Cutometer ${ }^{\circledR}$. Measurements after 2 hours also did not show significant difference between treatments (data not shown).

\section{Effects after 2- and 4-week period of daily applications}

Methods used for evaluating the effects of the formulations under study presented good results and it was possible to identify significant differences among the treatments. Thus, three formulations were chosen - vehicle
Neste estudo, os efeitos sobre o microrrelevo da pele após uma única aplicação das formulações foram avaliadas pelo Visioscan ${ }^{\circledR}$, mas os resultados não mostraram diferenças significativas entre os tratamentos estudados (dados não mostrados). As propriedades mecânicas da pele foram avaliadas usando um Cutometer ${ }^{\circledR}$. Medidas após 2 horas também não apresentaram diferença significativa entre os tratamentos (dados não mostrados).

\section{Efeitos após 2 - e 4-semanas de aplicações}

Os métodos utilizados para avaliar os efeitos das formulações em estudo apresentaram bons resultados e foi possível identificar diferenças significativas entre os tratamentos. Assim, foram escolhidas três formula- 
(F1), vehicle with chamomile extract (F3) and vehicle with apigenin (F4) - in order to evaluate their effects on the skin after a 2- and 4- week period of study.

Two volunteer groups were used for the evaluation of the cosmetics efficacy during 4 weeks of daily applications. One group applied the formulation F1on one forearm and on the other, the formulation F3. The other group applied the formulations F1 and F4 twice a day during 4 weeks, respectively.

On the face, one group of volunteers applied the formulation F3 and the other group applied the formulation F4 twice a day during 4 weeks. The measurements were done on 0, 2- and 4-weeks and the results obtained were compared.

An increase in stratum corneum water content was observed. This increment was more evident after 4-weeks of the application of the cosmetic formulations. The dry climate of the city where the study was carried out (Ribeirão Preto, São Paulo, Brazil) in the first two weeks of the study could be the reason why the results were more pronounced after 4-weeks of daily applications. Hence the same could be observed on the face. As on the face, like on the forearm, the best increments of stratum corneum water content were found when formulation F3 was applied (Figure 4). ções - veículo (F1), veículo com extracto de camomila (F3) e veículo com apigenina (F4) - para avaliar os seus efeitos sobre a pele após o 2 - e 4 - semanas de estudo. Dois grupos de voluntárias foram usadas para a avaliação da eficácia dos cosméticos durante 4 semanas de aplicações diárias . Um grupo aplicou a formulação F1 em um antebraço e, no outro, a formulação F3. O outro grupo aplicou as formulações F1 e F4, respectivamente, duas vezes por dia, durante 4 semanas.

$\mathrm{Na}$ cara, um grupo de voluntários aplicou a formulação F3 e o outro grupo aplicou a F4 formulação duas vezes por dia durante 4 semanas. As medições foram feitas em 0,2 - e 4 semanas e os resultados obtidos foram comparados entre si.

Observou-se um aumento do teor de água no estrato córneo. Este incremento foi mais evidente após 4 semanas de aplicação de formulações cosméticas. $\mathrm{O}$ clima seco da cidade onde o estudo foi realizado (Ribeirão Preto, São Paulo, Brasil), nas duas primeiras semanas de estudo poderia ser a razão pela qual os resultados foram mais pronunciadas após 4 semanas aplicações diárias. O mesmo pode ser observado na cara. Tal como na cara, no antebraço os melhores incrementos de teor de água do estrato córneo foram observados quando a formulação F3 foi aplicada (Figura 4).

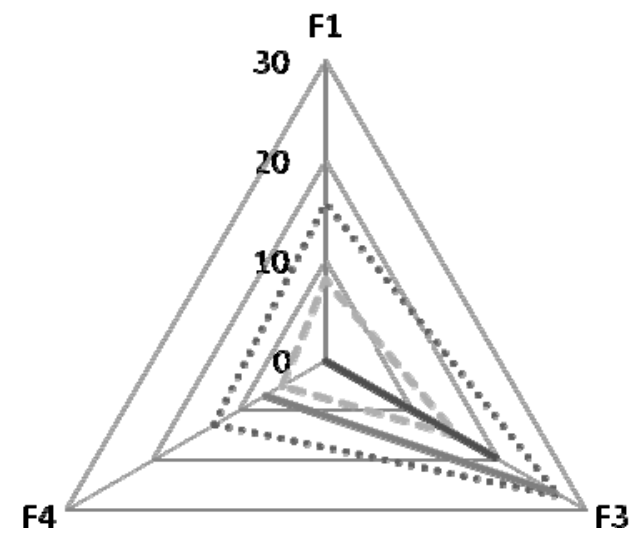

Figure 4- Increase (\%) of the stratum corneum water content of after 2-weeks (...) and 4-weeks application on the forearm (---) and 2-weeks (dark trace) and 4-weeks (light trace) on the face. F1 - vehicle, F3 - vehicle with 5.0\% of Matricaria chamomile glycolic extract, F4 - vehicle - with $0.01 \%$ of apigenin.

Figura 4 - Aumento (\%) do teor de água do estrato córneo após 2 semanas (....) e 4 semanas de aplicação no antebraço (---) e, 2-semanas (traço escuro) e 4 semanas (traço claro) de aplicação na cara. F1 - veículo, F3 - veículo com 5,0\% de extracto glicólico de Matricaria chamomilla L., F4 - veículo - com 0,01\% de apigenina.

A slight decrease in the water content of stratum corneum was observed after 4-weeks of application for all treatments. This was not statistically significant compared to the 2-weeks application.

Neither were there statiscally significant differences found between the treatments for all Visioscan ${ }^{\circledR}$ parameters (data not shown) and for Cutometer ${ }^{\circledR}$ parameters (data not shown).
Pôde ser observado um ligeiro decréscimo no conteúdo de água do estrato córneo, após 4 semanas de aplicação para todos os tratamentos, que não foi estatisticamente significativa comparando com a aplicação de 2 semanas.

Também não foram observadas diferenças estatisticamente significativas entre os tratamentos para todos os parâmetros medidos pelo Visioscan ${ }^{\circledR}$ (dados não apresentados) e para os parâmetros medidos pelo Cutometer ${ }^{\circledR}$ (dados não mostrados). 


\section{Discussion}

Chamomile has been used as an herbal medication since ancient times. It is still popular today and probably will continue to be used in the future because it contains various bioactive phytochemicals that could provide therapeutic effects (20). One of these therapeutic effects is the antioxidant activity, which was found in this study. Chamomile extract showed IC $50=0.14$ $\mu \mathrm{g} / \mathrm{mL}$. In addition to this study, Guimarães et al (21) found antioxidant properties. They used $\mathrm{DPPH}^{\bullet}$ scavenging activity, reducing power of $\mathrm{Fe}^{+3}, \beta$-Carotene bleaching inhibition and TBARS inhibition to evaluate the antioxidant activity of Matricaria recutita L. (German chamomile) methanol extract, its decoction and infusion and concluded that all samples presented antioxidant property.

With time the skin goes through various daily activities and it is constantly exposed to oxidative stress induced by reactive oxygen species (ROS) that will cause further damage. ROS are generated both from endogenous sources, such as byproducts of aerobic oxidation or cellular response to inflammation, and external pro-oxidant stimuli, such as ultraviolet radiation (2). According to Tang and Bhushan (22) skin cream can prevent or relieve these damages. Therefore, a skin care cream that contains botanical extracts with proved antioxidant activity is indeed very useful for improving the skin's condition.

Water plays important roles in maintaining the good condition of the skin. In the stratum corneum, water interacts with a natural moisturizing factor and keratin to give elasticity to the stratum corneum (23). In the dermis, the dermal fluid correlates with the skin elasticity. Water is also a crucial factor in the keratin layer barrier function and structure. In soft and flexible skin, the water content of the keratin layer is between $10 \%$ and $30 \%$ (22). For these reasons, it is very important to measure the hydration level of the skin.

In this study, two methods were used to evaluate the variation in the skin hydration after a single application or daily application of the formulations containing or not $\alpha$-bisabolol (F2), chamomile extract (F3) and apigenin (F4): a) stratum corneum water content which was measured using a skin capacitance meter and b) transepidermal water loss (TEWL) which was measured with an evaporimeter.

According to Loo et al (24), TEWL is a good indicator of impaired barrier function of the stratum corneum. An increase in $T E W L$ indicates a disruption of the stratum corneum and loss of intercellular lipids. In this study, the formulations contributed to decrease the transepi-

\section{Discussão}

A camomila tem sido utilizada como um medicamento, desde os tempos antigos, ainda popular hoje e, provavelmente continuará a ser utilizada no futuro, porque contém vários fitoquímicos bioactivos que podem proporcionar efeitos terapêuticos (20). Um destes efeitos terapêuticos é a actividade antioxidante, a qual foi encontrada neste estudo. $\mathrm{O}$ extracto de camomila apresentou $\mathrm{IC}_{50}=0,14 \mathrm{ug} / \mathrm{mL}$. Assim como no presente estudo, Guimarães et al (21) encontraram propriedades antioxidantes. Eles usaram os ensaios de atividade sequestradora $\mathrm{DPPH}^{\bullet}$, redução do poder do íon $\mathrm{Fe}^{+3}$, inibição do branqueamento $\beta$-caroteno e inibição de TBARS para avaliar a atividade antioxidante extracto de metanólico de Matricaria recutita L. (camomila alemã), da sua decocção e infusão e concluíram que todas as amostras apresentaram propriedade antioxidante.

Com o tempo, a pele passa por diferentes atividades diárias, assim como, ela está constantemente exposta ao estresse oxidativo induzido por espécies reativas de oxigênio (ROS) que irão causar danos futuros. As ROS são geradas tanto a partir de fontes endógenas, tais como subprodutos de oxidação aeróbica ou em resposta celular a inflamação, e à estímulos externos pró-oxidantes, tais como a radiação ultravioleta (2). De acordo com Tang e Bhushan (22) os cremes cosméticos podem prevenir ou aliviar esses danos. Portanto, um creme de cuidado da pele que contém extractos botânicos com actividade antioxidante comprovada é realmente muito útil para melhorar as condições da pele.

A água desempenha um importante papel na manutenção das boas condições da pele. No estrato córneo, a água interage com o factor natural de hidratação e com a queratina para dar elasticidade ao estrato córneo (23). $\mathrm{Na}$ derme, o líquido dérmico se correlaciona com a elasticidade da pele. A água também é um factor crucial para a função da camada de queratina e da estrutura. Na pele macia e flexível, o teor de água da camada de queratina está entre $10 \%$ e $30 \%$ (22). Por estas razões, é muito importante medir o nível de hidratação da pele. Neste estudo, foram utilizados dois métodos para avaliar a variação na hidratação da pele, após uma única aplicação ou aplicação diária das formulações contendo ou não $\alpha$-bisabolol (F2), extracto de camomila (F3) e apigenina (F4): a) teor de água do estrato córneo, que o foi medido utilizando um medidor de capacidade de pele e b) perda transepidérmica de água (PTEA) que foi medida com um evaporímetro.

De acordo com Loo et al (24), a PTEA é um bom indicador da função de barreira do estrato córneo prejudicada. Um aumento na PTEA indica uma perturbação no estra- 
dermal water loss on the forearm of the volunteers, especially the formulation containing chamomile extract. The main objectives of skin cream development are to assist the keratin layer in restoring the lost moisture and the regular packing of the lipid lamellae, normalizing the cellular turnover, and finally to repair the skin function and improve its feel (22).

According to Curdy et al. (25) formulation excipients may enhance active ingredient penetration into the $\mathrm{SC}$ by decreasing the membrane resistance (as in the case of penetration enhancers) or by increasing skin hydration. In this study, an increase in the skin hydration for the formulations containing chamomile extract was observed. Therefore, the use of this ingredient in dermocosmetic formulations may increase the penetration of the active compounds through the skin, as was verified by Melfort et al (26). The same authors carried out a study in human volunteers and demonstrated that chamomile flavonoids and essential oils penetrate below the skin surface into the deeper skin layers.

Up to now, data provided in the literature suggest the use of biophysical techniques in the non-invasive measurements of skin improvement. Concerning skin microrelief, according to Pena Ferreira et al (27) in recent years, several techniques have been developed to measure the skin properties objectively, and few commercially available instruments have been used in dermocosmetic research. In the present study, Visioscan ${ }^{\circledR}$ was used to measure microrelief skin characteristics such as smoothness, roughness, scaliness and wrinkles. Visioscan $^{\circledR}$ was considered by the same authors as very useful for a direct study on the skin surface and may be suitable as a routine method in wrinkle evaluation. However, in the present study, it was not possible to find significant differences between the formulations and control.

As non-invasive equipment, Cutometer ${ }^{\circledR}$ has made it possible to study the mechanical properties of skin and evaluate the effect of cream when used in certain conditions (28). Although the results were not considered statistically significant, they indicate that the effects of chamomile extract after single or 2- and 4-weeks of daily applications were more pronounced on hydration properties of skin. This can imply that it may be possible to find significant effects on mechanical properties of skin if the treatments were applied for a longer period of time.

This integrative approach offered a holistic overview about the improvement of skin biophysical properties after applying formulations with chamomile extract or its isolated compounds, $\alpha$-bisabolol and apigenin.

Knowledge of antioxidant activity of chamomile extract was indeed very useful for a better understanding to córneo e perda de lípidos intercelulares. Neste estudo, as formulações contribuíram para diminuir a perda de água transepidérmica no antebraço das voluntárias especialmente a formulação contendo extracto de camomila. Os principais objectivos do desenvolvimento de cremes para a pele são ajudar a camada de queratina no restabelecimento da perda de humidade e a regulação das lamelas lipídicas, normalizando a renovação das células e, finalmente, para reparar a função da pele e melhorar o seu toque (22). De acordo com Curdy et al (25) os ingredientes da formulação podem aumentar a penetração do ingrediente activo no estrato córneo, diminuindo a resistência da membrana (tal como no caso de promotores de penetração) ou aumentando a hidratação da pele. Neste estudo, verificou-se o aumento da hidratação da pele para as formulações que contêm extracto de camomila. Assim, a utilização deste ingrediente em formulações dermocosmética pode aumentar a penetração das substâncias activas através da pele, uma vez que foi verificado por Melfort et al (26). Os mesmos autores realizaram um estudo em voluntários humanos e demonstraram que os flavonóides de camomila e óleos essenciais penetrarm nas camadas mais profundas da pele.

Até agora, os dados apresentados na literatura sugerem a utilização das técnicas biofísicas nas medições não invasivas da melhoria da pele. No que diz respeito ao microrrelevo pele, de acordo com Pena Ferreira et al (27), nos últimos anos, várias técnicas têm sido desenvolvidas para medir as propriedades da pele de forma objectiva, e poucos instrumentos disponíveis comercialmente têm sido utilizados em investigação dermocosmética. No presente estudo, foi utilizado o Visioscan ${ }^{\circledR}$ para medir características do microrrelevo da pele, tais como a suavidade, a rugosidade, a descamação e as rugas. Visioscan ${ }^{\circledR}$ foi considerado pelos mesmos autores como muito útil para um estudo directamente sobre a superfície da pele e pode ser apropriado como um método de rotina na avaliação de rugas. No entanto, no presente estudo, não foi possível determinar diferenças significativas entre as formulações e o controlo.

Como equipamento não-invasivo, o Cutometer ${ }^{\mathbb{B}}$ tornou possível estudar as propriedades mecânicas da pele e avaliar o efeito do creme nas condições de utilização (28). Embora os resultados obtidos não tenham sido considerados estatisticamente significativos, estes indicam que os efeitos do extracto de camomila, após única aplicação ou 2 - e 4 semanas de aplicação diária foram mais pronunciados nas propriedades de hidratação da pele, o que pode implicar que seja possível encontrar efeitos significativos sobre as propriedades mecânicas da pele, se os tratamentos forem aplicados por um período de tempo mais longo. Esta abordagem integrada ofereceu uma visão holística sobre a melhoria das propriedades biofísicas da pele após 
of the best results obtained for the formulation containing chamomile extract.

According to the results obtained, it was possible to conclude that plant extracts offer substantial advantages over their individual components, i.e. chamomile extract, due to the mixture of antioxidants was effective in neutralizing free radicals and therefore presents potential in cosmetic formulations for this purpose.

The combined results from the present study clearly demonstrate that chamomile is an important medicinal plant for cosmetic proposals. Based on this study, formulations containing chamomile extract seem to provide important benefits to skin hydration and maintaining the skin barrier function.

\section{Acknowledgment}

The authors thank FAPESP for granting financial support for this study.

\section{Conflict of Interest}

The authors declare that there is no financial or personal relationship that can be understood as representing a potential conflict of interest. a aplicação de formulações com extracto de camomila ou seus compostos isolados, $\alpha$-bisabolol e apigenina.

O conhecimento da actividade antioxidante de extracto de camomila foi realmente muito útil para uma melhor compreensão dos melhores resultados obtidos para a formulação que contém extracto de camomila. De acordo com os resultados obtidos, foi possível concluir que os extractos de plantas oferecem vantagens substanciais sobre os seus componentes individuais, isto é, extracto de camomila, devido à mistura de antioxidantes foi eficaz na neutralização de radicais livres e, portanto, apresenta potencial em formulações cosméticas com este propósito.

Os resultados combinados do presente estudo demonstram claramente que a camomila é uma planta medicinal importante para propostas cosméticas. Com base neste estudo as formulações contendo extracto de camomila parecem fornecer benefícios importantes para a hidratação e manutenção da função de barreira da pele.

\section{Agradecimento}

Os autores agradecem a FAPESP pela a concessão de apoio financeiro para este estudo.

\section{Conflito de interesses}

Os autores declaram que não há nenhuma relação financeira ou pessoal, que pode ser entendida como representando um potencial conflito de interesses. 


\section{References / Referências}

[1]. Palmer DM, Kitchin JS. A Double-blind, randomized, controlled clinical trial evaluating the efficacy and tolerance of a novel phenolic antioxidant skin care system containing Coffea arabica and concentrated fruit and vegetable extracts. J Drugs Dermatol 2010; 9: 1480-1487.

[2]. Santa-María C, Revilla E, Miramontes E, Bautista J, García-Martínez A, Romero E, Carballo M, Parrado J. Protection against free radicals (UVB irradiation) of a water soluble enzymatic extract from rice bran. Study using human keratinocyte monolayer and reconstructed human epidermis. Food Chem Toxicol 2010; 48: 83-88.

[3]. Dal Belo SE, Gaspar LR, Maia Campos PMBG. Photoprotective effects of topical formulations containing a combination of Ginkgo biloba and green tea extracts. Phytother Res 2011; 25: 1854-1860.

[4]. Dal Belo SE, Gaspar LR, Maia Campos PMBG. Moisturizing effect of cosmetic formulations containing Aloe vera extract in different concentrations assessed by skin bioengineering techniques. Skin Res Technol 2006; 12: 241-246.

[5]. Gianeti MD, Mercurio DG, Maia Campos PMBG. The use of green tea extract in cosmetic formulations: not only an antioxidant active ingredient. Dermatol Ther 2013; 26: 267-271.

[6]. Bedi MK, Shenefelt PD. Herbal therapy dermatology. Arch Dermatol 2002; 138; 232 242.

[7]. Aburjai T, Natsheh FM. Plants used in cosmetics. Phytother Res 2003; 17: 987-1000.

[8]. Baumann LS. Less-known botanical cosmeceuticals. Dermatol Ther 2007; 20: 330-342.

[9]. Forrer M, Kulik EM, Filippi A, Waltimo T. The antimicrobial activity of $\alpha$-bisabolol and tea tree oil against Solobacterium moorei, a Gram-positive bacterium associated with halitosis. Arch Oral Biol 2013; 58:10-16.

[10]. Rocha NF, Rios ER, Carvalho AM, Cerqueira GS, Lopes Ade A, Leal LK, Dias ML, de Souda DP, de Sousa FC. Anti-nociceptive and anti-inflammatory activities of (-) - $\alpha$ - bisabolol in rodents. Naunyn Schmiedebergs Arch Pharmacol Sci 2011; 384: 525-533.
[11]. Mota ML, Lobo LT, Costa JM, Rocha HA, Rocha e Silva LF, Pohlit AM, Neto VF. In vitro and in vivo antimalarial activity of essencial oils and chemical components from three medicinal plants found in northeastern Brazil. Planta Med 2012; 78: 658-664.

[12]. Das S, Das J, Paul A, Samadder A, Khuda-Buksh. Apigenin, a bioactive flavonoid from Lycopodium clavatum, stimulates nucleotide excision repair genes to protect skin keratinocytes from ultraviolet B-induced Reactive Oxygen Species and DNA damage. J Acupunct Meridian Stud 2013; 6: 252-262.

[13]. Lademman J, Ritcher H, Astner A, Patzelt A, Knorr F, Sterry W, Antoniou Ch. Determination of the thickness and structure of the skin barrier by in vivo laser scanning microscopy. Laser Phys Lett 2008; 4: 311-315.

[14]. Luebberding S, Krueger N, Kersher M. Skin physiology in men and women: in vivo evaluation of 300 people including TEWL, SC hydration, sebum content and skin surface pH. Int J Cosmet Sci 2013, 35: 477-483.

[15]. Ohno H, Nishimura N, Yamada K, Shimizu Y, Iwase S, Sugenoya J, Sato M. Effects of water nanodroplets on skin moisture and viscolealsticity during air conditioning. Skin Res Technol 2013; 19: 375-383.

[16]. Mercurio DG, Segura JH, Demets MBA, Maia Campos PMBG. Clinical scoring and instrumental analysis to evaluate skin types. Clin Exp Dermatol 2013; 38, 302-309.

[17]. Capitani RD, Mercúrio DG, Camargo Jr FB, Maia Campos PMBG. Stability and clinical efficacy of moisturizing cosmetic formulations containing Vitamins $\mathrm{C}$ and $\mathrm{E}$. Biomed and Biopharm Res 2013; 9: 215-224.

[18]. Nile SH, Khobragade CN, Park SW. Optimized and Comparative Antioxidant Assays and Its Applications in Herbal and Synthetic Drug Analysis as an Antioxidants. Mini-Reviews Med Chem 2012; 12: 1007-1014.

[19]. Wagemaker TAL, Pereira KC, Maia Campos PMBG. Efeitos imediatos de formulações cosméticas contend óleo de café na hidratação e microrrelevo da pele. In. $24^{\circ}$ Congresso Brasileiro de Cosmetologia, São Paulo, Brazil, 2011.
[20]. Srivastava JK, Gupta S. Health promoting benefits of chamomile in the elderly population. In: Complementary and alternative therapies and the aging population an evidence-based approach. Elsevier, Amsterdan, NE. 2009.

[21]. Guimarães R, Barros L, Dueñas M, Calhelha R, Carvalho AM, Santo-Buelga C, Queiroz MJRP, Ferreira ICFR. Infusion and decoction of wild German chamomile: Bioactivity and characterization of organic acids and phenolic compounds. Food Chem 2013; 136 (2): 947-954.

[22]. Tang W, Bhushan B. Adhesion, friction and wear characterization of skin and skin cream using atomic force microscope. Colloids Surf B Biointerfaces 2010; 76: 1-15.

[23]. Nakagawa N, Matsumoto M, Sakai S. In vivo measurement of the water content in the dermis by confocal raman spectroscopy. Skin Res Technol 2010; 16: 137-141.

[24]. Loo CH, Basri M, Ismail R, Lau HLN, Tejo BA, Kathimati MS, Hassan HA, Choo YM. Effects of compositions in nanostructure lipid carriers (NLC) on skin hydration and occlusion. Int J Nanomedicine 2013; 8:13-22.

[25]. Curdy C, Naik A, Kalia YN, Alberti I, Guy RH. Non-invasive assessment of the effect of formulation excipients on stratum corneum barrier function in vivo. Int J Pharm 2004; 271: 251-256

[26]. Merfort I, Heilmann J, Hagedorn-Leweke $\mathrm{U}$, Lippold BC. In vivo skin penetration studies of camomile flavones. Pharmazie 1994; 49: 509-511.

[27]. Pena Ferreira MR, Costa PC, Bahia FM. Efficay of anti-wrinkle products in skin surface appearance: a comparative study using non-invasive methods. Skin Res Technol 2010; 16, 444-449.

[28]. Salvini C, Massi D, Cappetti A, Stante M, Cappugi P, Fabbri P, Carli P. Application of optical coherence tomography in non-invasive characterization of skin vascular lesions. Skin Res Technol 2008; 14: 89-92. 